UK, a careful analysis of diagnostic procedures and treatment regimens has to be undertaken to plan the most effective way of using limited funds for the benefit of the maximum number of people, as is done in India ${ }^{2}$ and East Africa. ${ }^{3}$ Of course, basic diagnostic skills are required everywhere; extensive practice at applying them to local people with problems common in the local community are also required. But the doctor who qualifies unable to function effectively within the limits set by local resources and to use these resources to the best advantage seems to me to be a failure of medical education whom the country had better have not trained at all or, rather, who ought to have had a different medical education.

JOYCE LEESON

Department of Social and Preventive Medicine, University of Manchester

SIR,-I did not feel that the most interesting article by $\mathrm{Dr} B$ Senewiratne and others (4 October, p 27) should be allowed to pass without comment. It contained much sound common sense which is relevant not only to the training of postgraduates in this country but to the training of medical students. Fashions in education come and go. Many of us have our special interests-some in nephrology, some in teratology, some in cardiology, some in mental deficiency, some in extremely rare diseases, and some in the normal child-but whatever our interest, and whatever the popular subject at the time, those who plan teaching must preserve a sense of balance and not overemphasise their own interest or one subject at the cost of others of equal or greater importance.

Of course all students have to be taught about the vital importance of the social aspects of medicine, of surgery, paediatrics, obstetrics, and other subjects, and probably most of us have taught that in outpatients, casualty, and the wards. These social aspects greatly interest students if properly taught, but students must also be taught about illness and disease, how to recognise the sick child, and how to treat the common important conditions. I believe that in Britain there is a danger that too much time may be devoted to social medicine. If one adds one subject or increases the time allotted to it one has to take it off something else. I fear that after some modern curricula new graduates will be unable to recognise an ill patient when they see one, and not know what to do with him.

The imbalance which Dr Senewiratne and others describe in Sri Lanka, with 973 hours devoted to teaching public health and only 979 hours to the rest of medicine (and 256 hours to paediatrics) when half the population is under the age of 15 , could well occur here and elsewhere.

\section{RONALD ILLINGWORTH}

The Children's Hospital, Sheffield

\section{Mao's China}

SIR,-It is sad to read so many testimonials to life in China. We should remember that the ruler is a pitiless dictator-a man of extraordinary genius, on a par with Hitler and Stalin. We should remember the attack on South Korea involving Chinese troops and brain-washing by torture; the imprison- ment of people in solitary confinement in tiny cells for no crime and after no trial; the cultural revolution which encouraged young thugs to beat up the intelligent people. We should note, too, that the Chinese fish in any pool where they think they can cause trouble. In how many African countries are they doing the devil's work?

Apparently everybody in China obeys. Are there no non-conformists? And what happens to them? I do not suppose that more than a handful even of Chinese know what is happening in that enormous country, yet the latest admirers (11 October, p 99), after three weeks' visit, tell us that they have abandoned acquisitiveness-in other words they have abolished original sin. I remember in my youth reading in the liberal Daily News about the Russian revolution-how marvellous that out of this terrible war should have come the dawn of freedom for the Russian people. I remember all the good things Mussolini did in Italy and how Hitler cured unemployment.

I wish some of your correspondents could bring home from China some news of missing Christians. The thoughts of Chairman Mao are poor spiritual food indeed and not a good exchange for freedom. The price of freedom is a heavy one. I am beginning to wonder if we are any longer prepared to pay it. If not, perhaps we should welcome someone who would tell us exactly what to think and what to do.

London NW4

R W Cockshut

\section{"Bright ring of words"}

SIR,-May I congratulate you on the vastly improved appearance of the $B M F$ since 4 October? In $1963^{1}$ I deprecated its antique house style, which involved scattering capital letters throughout the headlines, captions, legends, and so on, as though sprinkled from a pepperpot, and suggested you join the rest of us in the 20th century. It has taken time for my suggestion to bear fruit, but the result is worth the wait.

Box 30125,

H de Glanville

Nairobi

1 de Glanville, H, British Medical fournal, 1963, $1,1417$.

\section{Treatment of clonidine overdose}

SIR,-It is unfortunate that the interesting short communication on clonidine overdose by $\operatorname{Dr} \mathrm{S} N$ Hunyor and others (4 October, p 23) should include the statement that "forced frusemide diuresis seems to be an effective means of removing clonidine." This conclusion appears to be drawn from the observations on their first patient, who received frusemide and excreted $47 \%$ of the ingested clonidine in the urine within 24 hours. Since healthy subjects excrete about $44 \%$ of single doses of clonidine in the urine within 24 hours $^{1}$ without frusemide it seems unlikely that the diuretic made much difference, although it would probably be wiser to draw no conclusion from this single observation.

The authors themselves did no more than administer a single dose of $50 \mathrm{mg}$ frusemide, but the term "forced frusemide diuresis" implies a more elaborate procedure ${ }^{2}$ which is potentially hazardous and would be particularly undesirable in hypertensive patients with cardiovascular complications. Statements of this kind are readily incorporated into the folk lore of clinical toxicology and are difficult to remove. ${ }^{3}$ I suggest that the treatment of clonidine overdose should not include any form of forced diuresis until some evidence for its efficacy has been produced.

L RAMSEY

Western Infirmary

1 Rehbinder, D, Catapres in Hypertension. London, Butterworths, 1970

2 Linton, A L, Luke, R G, and Briggs, J D, Lancet,

Matthew, H, British Medical fournal, 1971, 1, 519.

\section{Diseases of central nervous system}

SIR,-Since when has myasthenia gravis (18 October, $p$ 152) been a disease of the brain or spinal cord?

J M K SPALDING Oxford

\section{Antipsychiatrists and ECT}

SIR,-Your leading article (4 October, p 1) highlights the importance of encouraging research into the mechanism by which ECT produces improvement in depressive illness. Possibly it stimulates the sympathetic system. Weil-Malherbe ${ }^{1}$ showed that ECT raised blood levels of adrenaline briefly. It has also been shown to cause a rise in plasma ACT ${ }^{2}$

The effect of ECT might be directly on cerebral cell membranes. If so, membrane stimulation could well produce an increase in intra- and hence extracellular $3^{\prime} 5^{\prime}$ cyclic adenosine monophosphate (cAMP). This possibility was investigated by Hamadah, ${ }^{3}$ who found rises in urinary cAMP on the day of ECT. In our recent study on urinary cAMP and ECT we could find no such rises. ${ }^{4}$ Further studies on ECT are urgently required because, in the final analysis, the only way to counter criticisms of it as a therapeutic tool will be a clear understanding of its mechanism of action.

Perhaps if the same resources were put into this field as into the research and development of a new drug in the pharmaceutical industry ECT would no longer remain a mystery and would take its rightful place in psychiatric practice.

Department of Chemistry,

R B MOYES

University of Hull,

Broadgate Hospital,

I C A MOYES

Beverley, North Humberside

1 Weil-Malherbe, H, fournal of Mental Science, 1955, 101, 156

2 Allen, J P, et al, American fournal of Psychiatry, 1974, 131. 1225 3 Hamadah, $\mathbf{K}$, et al, British Medical fournal, 1972, 3, 439.

4 Moyes, I C A, and Moyes, R B. In press.

\section{Silicone foam sponge for pilonidal sinus}

SIR,-The paper by Mr R A B Wood and Professor L E Hughes on silicone foam sponge for packing granulating wounds (18 October, $p$ 131) was instructive. The statistics and disoussion which follow about their series of patients with pilonidal sinus is bewildering. Some years ago Mr Peter Lord 